\title{
Income Inequality Tolerance and Preferences for Redistribution in Turkey
}

\author{
Ayfer Karayel \\ Department of Economics, Galatasaray University, Turkey \\ ayferkarayel@yahoo.com
}

\begin{abstract}
In this paper, the extent to which redistribution is desired by the Turkish and its determinants are estimated. For this purpose, the 2009 Social Inequality Module of the International Social Survey Programme is used. Finding the attitudinal differences between urban and rural region residents, and understanding whether these can be attributed to educational differences is additionally aimed. The estimations indicate that pro-redistribution preferences are shaped by distributive justice considerations captured by the question on just payment at work. Having no or low educational qualification, living in urban regions and small cities also play an important role. Being in the lowest income categories is also associated with higher demand for redistribution. The attitudinal difference between rural and urban residents cannot be attributed to differences in the educational levels, differences in cultural values and/or income levels seem to play an important role. This study's finding that women are more tolerant of income inequality than men is the opposite of the previous finding based on the 2011 WVS data, and of the more usual finding in other studies. Hard work has a non- significant effect in the present study although it was one of the determinants of pro-redistribution preferences previously. The impact of income is similar to previous analysis' finding. However, mixed results were found in the previous analysis relative to the effect of living in a specific region. The effects are more homogeneous with ISSPA data, as all of the regions with significant coefficients have relatively reduced support for redistribution than Istanbul.
\end{abstract}

Keywords Preferences for Redistribution, Turkey, International Social Survey Programme

\section{INTRODUCTION}

Cross-country analyses of the determinants of people's preferences for redistribution highlight primarily the importance of socio-economic factors comprising current income, occupational status, prospect for upward mobility, along with personal history and endowments such as education, social status, risk aversion, subjective social class, race and marriage status. Beliefs in the fairness of the allocation mechanism, perceived moral worth of the poor, individual autonomy, left-right political orientation, active union membership, cultural factors and place of residence are other mostly accepted determining factors in empirical research.

The highly cited Meltzer and Richard model (1981) implies that the median voter will vote for redistributive politics in countries where income inequality is high, that is where median income is lower than mean income and there are net gains from redistribution. Along with the analyses confirming this hypothesis and supremacy of economic factors (Corneo and Grüner, 2002; Alesina, Di Tella and MacCulloch, 2004; Alesina and Giuliano, 2009; Guillaud, 2011; Neher, 2012), controversial evidence is also found by certain studies. When a great number of welfare recipents are a racial minority (Luttmer, 2001; Alesina and La Ferrara, 2001, 2005), when the poor expect an upward social mobility which may in turn depend on education and institutional context (Piketty, 1995; Bénabou and Ok, 2001; Alesina, Di Tella and MacCulloch, 2004; Alesina and La Ferrara, 2005; Corneo and Grüner, 2002; Alesina and Giuliano, 2009; Guillaud, 2013). The limitations of the Meltzer and Richard hypothesis and derived homo oeconomicus effect (Corneo and Grüner 2002), are also pointed to in some analyses that focused on developing countries (Haggard, Kaufman and Long, 2013; Im, 2014). The study by Haggard et al. draws attention to the heterogeneity among the poor and to the limited or dampening effects of inequality on demands for redistribution. The study by Im reveals that limited educational opportunities in rural areas of China lead to increased authoritarianism and social dominance orientation among the poor which in turn lead to higher tolerance of inequality by people of lower socioeconomic status. This finding shows the complexity of the mechanisms of attitude formation as less educated individuals are found pro-redistribution in most cross-country or single-country studies (Verme, 2007; Neher, 2012; Gaeta, 2012; Haggard et al. , 2013). 
The model based on income and the distribution of income is extended by the introduction and significant results of other variables. Risk aversion is found to have a positive impact on preferences for redistribution, as more risk averse individuals are also more inequality averse and pro-redistribution (Ferrer-i-Carbonell and Ramos, 2010; Gaeta, 2012; Guillaud, 2013). Belonging to a lower social class than the middle also makes individuals inequality averse and pro-redistribution (Macunovich, 2011 ; Neher 2012 Guillaud 2013). Perception of unfairness of the allocation mechanism in society drive to favor more redistribution, other things equal (Fong, 2001 ; Piketty, 1999 ; Alesina and Angeletos, 2005 ; Corneo and Grüner, 2002 ; Cojocaru, 2011). Perceived moral worth of the poor and individual autonomy are two other variables (Neher, 2012) that may also be related to the belief in hard work for success and to the beliefs about mobility. Left-right political orientation affects also redistribution preferences although the reverse causality problem may occur (Kaltenthaler et al. 2008 ; Verme, 2007). Cultural factors, and welfare regime habits are shown to affect redistribution preferences as evidenced respectively in the specific contexts of the immigrants in the USA and in reunified Germany (Alesina and Giuliano, 2009 ; Luttmer and Singhal, 2011). With mixed evidence, demographic variables such as gender, age, marital and employment status, active union membership, religious orientation, and size of the city of residence are also found to shape preferences for redistribution.

Previous research for Turkey based on World Values Survey data supports the assumption that economic self-interest shapes individual preferences for redistribution (Karayel, 2015). The present study is based on data from International Social Survey Programme (ISSP) and aims to find the attitudinal differences between urban and rural region residents, and to understand whether these can be attributed to educational differences. The paper is organized as follows. Section 2 presents the methodology, data and variables. Section 3 presents the results of the empirical analysis, and the last section concludes.

\section{METHODOLOGY, DATA AND VARIABLES}

The econometric analysis draws on the fourth Social Inequality module of ISSP (2009) and uses a standard logit model. Turkish people's income inequality tolerance and preferences for redistribution are measured through the answer given to a five-steps scale question that asks repondents whether it is the responsibility of the government to reduce the differences in income between people with high incomes and those with low incomes. Answers are scaled as: $1=$ Strongly agree; $2=$ Agree; $3=$ Neither agree nor disagree; $4=$ Disagree; $5=$ Strongly disagree. This five-steps scale variable has been transformed to a binary response variable in which individuals holding strong redistributionist views are distinguished from all other responses (neutral and opposition views) by equalizing values of 1 and 2 to 1 , and values from 3 to 5 to 0 . This variable is labeled REDISTRIBUTION and used as the dependent variable capturing both inequality tolerance (or aversion) and preferences for redistribution. This question refers explicitly to government action for reducing income inequality, but it can be argued that inequality cannot be reduced by charitable action alone if people are averse to inequality.

Turkish respondents are between 18-87 years of age. Explanatory variables are selected among the available data with no or limited number of missing observations. Although some relevant variables that were not available in WVS data are available in the ISSP data, some of them could not be used, given the number of missing values and problem with data. One of them is the variable measuring subjective social mobility. Subjective social status variable indicating top bottom self placement on a scale is the other. Left-right political orientation variable is available in both WVS and ISSP data, but could not be used in the present estimations due to the high number of unrevealed preferences. Employment status and subjective social status variables also posed problems.

However, variables relative to size of the city of residence and to the type of the community (urban/rural) available for Turkey only in the ISSP data could be used, and most of the relevant variables are included. Explanatory variables used in the estimation are presented below with variable labels. Coefficients are interpreted relative to the reference category. Descriptive statistics of the variables are displayed in Table 1.

The variable measuring opinions about the importance of hard work for success (HWORK) has originally five categories. Answers ranging from the first to the third category, respectively "essential", "very important" and "fairly important" are assigned the value 1 and labeled "important". Answers in the fourth and fifth categories, respectively "not very important" and "not important at all" are assigned the value 0 and labeled "not important", this category being the reference. 
Another variable of interest is just pay (JUSTPAY) that asks respondents whether they would say they earn much less or much more than deserved. The original six categories of answers are recoded in four dummies where the first two categories are assigned the value 2 and labeled "less than deserved", the third category is assigned the value 1 and labeled "what is deserved", the fourth and fifth categories are assigned the value 0 and labeled "more than deserved", and finally, the sixth category composed of respondents who never worked is assigned the value 3 . The category with the lowest value, that is "more than deserved" is the reference.

Demographic variables are sex, age and marital status. Sex variable takes the values :" $1=$ Male $; 2=$ Female". "Male" is the reference category. The age variable is grouped in six categories as follows (AGE6CATEGORIES): $1=18-30 ; 2=31$ $40 ; 3=41-50 ; 4=51-60 ; 5=61-70 ; 6=71-87$. The first category is the reference. Marital status is indicated by two dummies: 1. Married; 0 . Not married (reference category). Widowed, divorced, separated and single individuals are all included in the "not married" category. This variable is labeled MARRIED.

The variable DEGREE shows highest educational level attained. The original six categories are recoded in four as follows: $1=$ No formal qualification (reference category); 2 = Lower qualification that comprises lowest and above lowest formal qualifications; 3 = Higher qualification that comprises higher and above higher secondary levels; $4=$ University degree.

The variable UNION recoded in two dummies, takes the value 1 for trade union members and the value 0 for individuals who were once member or never member (reference category).

Declared family income in Turkish Liras (TRY) of respondents are categorized in six groups: $1=0-999 ; 2=1000-1999 ; 3$ $=2000-3999 ; 4=4000-5999 ; 5=6000-8999 ; 6=9000-15600$. This variable is labeled as INCOMEF and the first category is the reference.

Attendance of religious services is indicated by the variable ATTEND which is recoded in five categories. The first category includes those who attend from five times a day up to five times a week. The second category ranges from once a week to three or two times a month (reference category). The third category ranges from once a month to several times a year. The fourth category ranges from once a year to less frequently than once a year, and finally, the fifth category includes those who never attend.

REGION is indicated by one of the following regions : 1. Istanbul; 2. Aegean; 3. Mediterranean; 4. Southeast Anatolia; 5. Western Anatolia; 6. Eastern Anatolia; 7. Western Black Sea; 8. Central Anatolia; 9. Central East Anatolia; 10. Eastern Black Sea; 11. Western Marmara; 12. North Eastern Anatolia. Istanbul is the reference.

Type of community variable, RURALURB, originally grouped in five categories is recoded in two dummies where residents in big cities, suburbs, town or small cities are assigned the value 0 and residents living in country villlages and rural areas are assigned the value 1. Finally, size of community variable, SIZE, indicates the population of the province where the interview took place. Turkey's provinces are grouped in five categories according to their population : 1 . More than 2 million habitants; 2. Between 1 and 2 million habitants; 3. Between 500000 and 1 million; 4 . Between 250000 and 500000 habitants; 5 . Less than 250000 habitants. The reference category is the first one.

\section{RESULTS}

Results are displayed in two models and as odds ratios in Table 2. Odds ratios are exponentiated coefficients; they correspond to negative coefficients when they are less than 1 and to positive coefficients when they are greater than 1 . For each categorical variable, they are interpreted relative to the reference category.

The first model (M1) excludes the educational level of respondents indicated by DEGREE. Educational level is introduced in the second model (M2 or complete model). Both models show that the feeling of being paid unjustly at work is associated positively and strongly with pro-redistribution attitudes compared to people who feel to be paid more than what is deserved. People who never worked support similarly more redistribution relative to the reference category. In the second model, those who think to be paid what is deserved show also more support for redistribution.

In both models, women are more tolerant of income inequality than men, considering that the less-than-1 odds ratio for female in the second model is significant and that in the first model is close to 10 percent significance level. This result is the opposite of the previous study's finding based on the 2011 WVS data, and of the more usual finding in other studies. 
When education is included, the decreased odds ratio suggests that the attitudinal difference between female and male is not attributable to educational level differences. A positive association is found only for the 41-50 years age category and pro-redistribution preferences relative to the youngest age category. Being married has no significant effect on attitudes.

The complete model (M2) indicates that the support for redistiribution is reduced with increasing educational levels, a result similar to that of most empirical findings. The complete model also indicates that the second lowest income category is more likely to support redistribution compared with the lowest. Coefficients are non-significant for higher income categories.

The odds ratio for people who never attend religious services is significant in the first model and close to 10 percent significance level in the complete model. This suggests that people who never attend religious services are highly tolerant of inequality and oppose to redistribution relative to the reference category.

All of the regions with significant coefficients have relatively more tolerance for inequality and reduced support for redistribution than Istanbul. When education is included, the coefficient of North Eastern Anatolia increases, the difference between North Eastern Anatolia and Istanbul is attenuated even if North Eastern Anatolia residents oppose more to redistribution than Istanbul residents. This suggests that the difference is partly attributable to educational level.

It is also interesting to note that rural residents do not support redistribution compared with urban residents. In the second model where education is included, rural residents oppose to redistribution by the government even more, similar to the case of female respondents : the attitudinal difference between rural and urban residents cannot be attributed to differences in the educational levels, differences in cultural values and/or income levels are likely to play an important role.

Finally, for all region sizes indicated by the number of inhabitants, the association is positive. As the size gets smaller, proredistribution preferences increase, excluding the non-significant coefficient for the size between 500000 and 1 million habitants.

\section{CONCLUSION}

The present analysis aims to find the determining factors of individual support for redistribution in Turkey based on the data from the 2009 ISSP Social inequality Module.

The estimations indicate that pro-redistribution preferences are shaped by distributive justice considerations captured by the question on just payment at work. Having no or low educational qualification, and living in urban regions and small cities also play an important role. Being in the lowest income categories is also associated with higher demand for redistribution. The attitudinal difference between rural and urban residents cannot be attributed to differences in the educational levels, differences in cultural values and/or income levels seem to play an important role.

Variables included in the present estimations that are comparable to those of the analysis based on WVS data are gender, hard work, being dissatisfied with the financial situation of the household (used as a proxy for income), being a union member, and region.

This study's finding that women are more tolerant of income inequality than men is the opposite of the previous finding based on the 2011 WVS data, and of the more usual finding in other studies. Hard work has a non- significant effect in the present study although it was one of the determinants of pro-redistribution preferences previously. The impact of income is similar to the previous finding. Being a union member's effect is non-significant in both studies. However, mixed results were found in the previous analysis relative to the effect of living in a specific region. The effects are more homogeneous with ISSPA data, as all of the regions with significant coefficients have relatively reduced support for redistribution than Istanbul. The difference between North Eastern Anatolia and Istanbul residents seems to be partly attributable to educational level.

\section{REFERENCES}

[1] Alesina, A. \& Angeletos, G. M. (2005). Fairness and redistribution. The American Economic Review, 95 (4), pp. $960-$ 980. 
[2] Alesina, A. , Di Tella, R. \& MacCulloch, R. (2004). Inequality and happiness : are Europeans and Americans different ? Journal of Public Economics, 88, pp. 2009-2042.

[3] Alesina, A. \& Giuliano, P. (2009). Preferences for Redistribution. NBER Working Paper 14825. Retrieved from: $<$ http://www. nber. org/papers/w14825>

[4] Alesina, A. \& E. La Ferrara. (2001) Preferences for redistribution in the land of opportunities. NBER Working Paper No. 8267.

[5] Alesina, A. \& La Ferrara, E. (2005). Preferences for redistribution in the land of opportunities. Journal of Public Economics, 89, pp. 897-931.

[6] Bénabou, R. \& Ok, E. (2001). Social mobility and the demand for redistribution : the POUM hypothesis. Quarterly Journal of Economics, 116, pp. 447-487.

[7] Cojocaru, A. (2011). Inequality and well being in transition economies : A non-experimental test of inequality aversion. Working Papers 238, ECINEQ, Society for the Study of Economic Inequality.

[8] Corneo, G. \& Grüner H. P. (2002). Individual Preferences for Political Redistribution. Journal of Public Economics, 83 (1), pp. 83-107.

[9] Ferrer-i-Carbonell, A. \& Ramos, X. (2010). Inequality Aversion and Risk Attitudes. IZA Discussion Paper no. 4703.

[10] Fong, C. (2001). Social preferences, self-interest and the demand for redistribution. Journal of Public Economics 82 , pp. 225-246.

[11] Gaeta, G. L. (2012). In the mood for redistribution. An empirical analysis of individual preferences for redistribution in Italy. Economics Bulletin, 32 (3), pp. 2383-2398.

[12] Guillaud, E. (2013). Preferences for redistribution : an empirical analysis over 33 countries. Journal of Economic Inequality, 11 (1), pp. 57-78.

[13] Haggard, S. , Kaufman R. R. , Long, J. D. (2013). Income, Occupation, and Preferences for Redistribution in the Developing World. Studies in Comparative International Development, 48 (2), pp. 113-140.

[14] Kaltenthaler, K. , Ceccoli, S., Gelleny, R. (2008). Attitudes toward Eliminating Income Inequality in Europe. European Union Politics, 9 (2), pp. 217-241.

[15] Karayel, A. (2015). Attitudes to Income Inequality and Preferences for Redistribution in Turkey. Forthcoming in the Proceedings of the 14th Eurasia Business and Economics Society Conference.

[16] Luttmer, E. F. P. \& Singhal, M. (2011). Culture, Context, and the Taste for Redistribution. American Economic Journal : Economic Policy, 3 (1), pp. 157-79.

[17] Meltzer, A. H. \& Richard, S. F. (1981). A Rational Theory of the Size of Government. Journal of Political Economy, 89 (5), pp. 914-27.

[18] Neher, F. (2012). Preferences for Redistribution around the World. Freie Universitat Berlin School of Business and Economics Discussion Paper, Economics 2012/2.

[19] Piketty, T. (1995). Social mobility and redistributive politics, Quarterly Journal of Economics, 110 (3), pp. 551-84.

[20] Piketty, T. (1999). Attitudes Toward Income Inequality in France : Do People Really Disagree ? Seminar notes no. 9918, C. E. P. R. E. M. A. P.

[21] Verme, P. , 2007. Happiness and Inequality Aversion Worldwide. Conference Paper. Retrieved from: <http://www. isid. ac. in/ planning/ConferenceDec07/Papers/PaoloVerme. pdf > 
Table 1: Descriptive statistics of variables

†Table 1: Descriptive statistics of variables

\begin{tabular}{|c|c|c|c|c|c|}
\hline Variable & Obs. & Mean & Std. Dev. & Min & $\operatorname{Max}$ \\
\hline \multicolumn{6}{|l|}{ REDISTRIBUTION } \\
\hline $\begin{array}{l}\text { 1. Responsibility of the Gov. } \\
\text { to reduce income differences }\end{array}$ & & 0.923 & 0.267 & 0 & 1 \\
\hline \multicolumn{6}{|l|}{0 . Indifferent or disagree } \\
\hline \multicolumn{6}{|l|}{ HARDWORK } \\
\hline 1. Important & & $0.960^{\circ}$ & 0.196 & 0 & 1 \\
\hline \multicolumn{6}{|l|}{0 Not important } \\
\hline \multicolumn{6}{|l|}{$\begin{array}{l}\text { JUSTPAY } \\
0 . \text { More than deserved }\end{array}$} \\
\hline $\begin{array}{l}\text { 1. What is deserved } \\
\text { 2. Less than deserved }\end{array}$ & & $\begin{array}{l}0.159 \\
0.435\end{array}$ & $\begin{array}{l}0.365 \\
0.496\end{array}$ & $\begin{array}{l}0 \\
0\end{array}$ & $\begin{array}{l}1 \\
1\end{array}$ \\
\hline 3. Never worked & & 0.398 & 0.490 & 0 & 1 \\
\hline SEX & 1569 & & & & \\
\hline \multicolumn{6}{|l|}{ 1. Male } \\
\hline 2. Female & & 0.527 & 0.499 & 0 & 1 \\
\hline \multicolumn{6}{|c|}{$\begin{array}{ll}\text { AGE6CATEGORIES } & 1563\end{array}$} \\
\hline $\begin{array}{l}\text { 1. } 18-30 \\
\text { 2. } 31-40 \\
\text { 3. } 41-50 \\
\text { 4. } 51-60 \\
\text { 5. } 61-70 \\
\text { 6. } 71-87\end{array}$ & & $\begin{array}{l}0.232 \\
0.180 \\
0.150 \\
0.091 \\
0.042\end{array}$ & $\begin{array}{l}0.422 \\
0.385 \\
0.358 \\
0.287 \\
0.201\end{array}$ & $\begin{array}{l}0 \\
0 \\
0 \\
0 \\
0\end{array}$ & $\begin{array}{l}1 \\
1 \\
1 \\
1 \\
1\end{array}$ \\
\hline \multicolumn{6}{|l|}{ MARRIED } \\
\hline 1. Married & & $0.726^{-}$ & $0.44 \overline{6}^{-}$ & 0 & 1 \\
\hline \multicolumn{6}{|l|}{ O. Not married } \\
\hline DEGREE & 1552 & & & & \\
\hline \multicolumn{6}{|l|}{ 1. No qualification } \\
\hline 2. Lower qualification & & 0.564 & 0.496 & 0 & 1 \\
\hline 3. Higher qualification & & 0.225 & 0.418 & 0 & 1 \\
\hline 4. University degree & & 0.083 & 0.275 & 0 & 1 \\
\hline UNION & 1553 & & & & \\
\hline 1. Member & & 0.031 & 0.173 & 0 & 1 \\
\hline 0. Not member & & & & & \\
\hline $\begin{array}{l}\text { INCOMEF } \\
\text { 1. } 0-999 \\
\text { 2. } 1000-1999 \\
\text { 3. } 2000-3999 \\
\text { 4. } 4000-5999 \\
\text { 5. } 6000-8999 \\
\text { 6. } 9000-15600\end{array}$ & 1272 & $\begin{array}{l}0.301 \\
0.133 \\
0.020 \\
0.011 \\
0.007\end{array}$ & $\begin{array}{l}0.459 \\
0.340 \\
0.142 \\
0.104 \\
0.084\end{array}$ & $\begin{array}{l}0 \\
0 \\
0 \\
0 \\
0\end{array}$ & $\begin{array}{l}1 \\
1 \\
1 \\
1 \\
1\end{array}$ \\
\hline
\end{tabular}




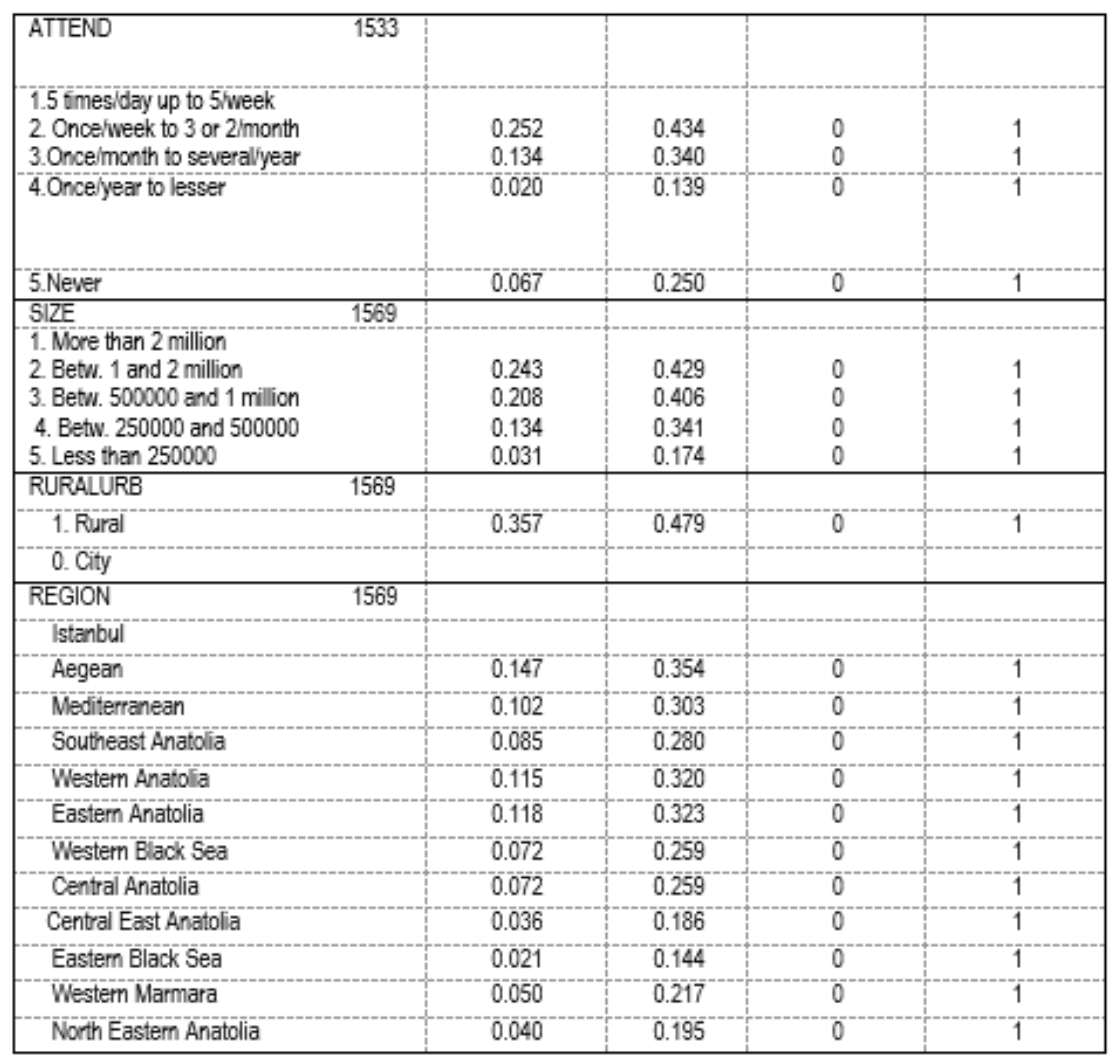

Source : ISSP - Social inequality (2009) 
Table 2 : Logit estimation results reporting odds ratios

\begin{tabular}{|c|c|c|}
\hline DEP. VAR.: INCOMEEQUALITY & $\begin{array}{c}\text { (M1) } \\
\text { Odds Ratio (Std. Error }\end{array}$ & $\begin{array}{c}\text { (M2) } \\
\text { Odds Ratio (Std. Error) }\end{array}$ \\
\hline \multicolumn{3}{|l|}{ HARDWORK } \\
\hline İmportant & $1.301(0.858)$ & $1.238(0.826)$ \\
\hline \multicolumn{3}{|l|}{ JUSTPAY } \\
\hline $\begin{array}{l}\text { 1. What is deserved } \\
\text { 2. Less than deserved } \\
\text { 3. Never worked }\end{array}$ & $\begin{array}{l}3.357(2.841) \\
15.894^{* \pm}(13.675) \\
11.728+10.273)\end{array}$ & $\begin{array}{l}4.101(3.476) \\
19.506^{+}(16.784) \\
13.130=(11.451)\end{array}$ \\
\hline \multicolumn{3}{|l|}{ SEX } \\
\hline 2. Female & $0.583(0.205)$ & $0.509^{*}(0.181)$ \\
\hline $\begin{array}{l}\text { AGE6CATEGORIES } \\
\text { 2. } 31-40 \\
\text { 3. } 41-50 \\
\text { 4. } 51-60 \\
\text { 5. } 61-70 \\
\text { 6. } 71-87\end{array}$ & $\begin{array}{l}1.345(0.475) \\
2.690^{ \pm \pm}(1.222) \\
1.326(0.526) \\
1.784(0.875) \\
0.935(0.578)\end{array}$ & $\begin{array}{l}1.198(0.434) \\
2.340^{*}(1.097) \\
0.963(0.406) \\
1.256(0.655) \\
0.577(0.386)\end{array}$ \\
\hline \multicolumn{3}{|l|}{ MARRIED } \\
\hline Married & $0.945(0.284)$ & $0.799(0.253)$ \\
\hline \multicolumn{3}{|l|}{ DEGREE } \\
\hline $\begin{array}{l}\text { 2. Lower qualification } \\
\text { 3. Higher qualification } \\
\text { 4. University degree }\end{array}$ & & $\begin{array}{l}0.827(0.377) \\
0.404^{ \pm}(0.222) \\
0.335^{ \pm}(0.221)\end{array}$ \\
\hline $\begin{array}{l}\text { INCOMEF } \\
\text { 2. } 1000-1999 \\
\text { 3. } 2000-3999 \\
\text { 4. } 4000-5999 \\
\text { 5. } 6000-8999 \\
\text { 6. } 9000-15600\end{array}$ & $\begin{array}{l}1.350(0.413) \\
1.480(0.649) \\
0.807(0.582) \\
2.462(2.675) \\
0.475(0.463)\end{array}$ & $\begin{array}{l}1.692^{*}(0.544) \\
1.815(0.817) \\
1.022(0.760) \\
2.800(3.067) \\
0.680(0.682)\end{array}$ \\
\hline \multicolumn{3}{|l|}{ UNION } \\
\hline Member & $2.407(2.089)$ & $2.869(2.490)$ \\
\hline
\end{tabular}

\begin{tabular}{|c|c|c|}
\hline $\begin{array}{l}\text { ATTEND } \\
\text { 1.5 timesiday up to } 5 \text { /week } \\
\text { 3. Oncelmonth to severallyear } \\
\text { 4. Oncelyear to lesser } \\
\text { 5. Never }\end{array}$ & $\begin{array}{l}0.883(0.308) \\
1.496(0.711) \\
1.825(2.027) \\
0.433^{\star}(0.219)\end{array}$ & $\begin{array}{l}0.968(0.338) \\
1.798(0.876) \\
1.721(1.907) \\
0.479(.241)\end{array}$ \\
\hline $\begin{array}{l}\text { REGION } \\
\text { Aegean } \\
\text { Mediterranean } \\
\text { Southeast Anatolia } \\
\text { Western Anatolia } \\
\text { Eastem Anatolia } \\
\text { Western Black Sea } \\
\text { Central Anatolia } \\
\text { Central East Anatolia } \\
\text { Eastem Black Sea } \\
\text { Westem Marmara } \\
\text { North Eastern Anatolia }\end{array}$ & $\begin{array}{l}1.880(1.403) \\
0.075^{\star * *}(0.051) \\
0.213^{* \pm}(0.165) \\
0.247^{* * *}(0.124) \\
0.349(0.228) \\
0.113^{* \pm *}(0.085) \\
0.152^{* \pm}(0.124) \\
0.257(0.266) \\
0.352(0.365) \\
0.611(0.757) \\
0.077^{* * *}(0.069)\end{array}$ & $\begin{array}{l}1.775(1.328) \\
0.070^{* t *}(0.049) \\
0.183^{* t}(0.147) \\
0.255^{* * \pm}(0.130) \\
0.420(0.288) \\
0.104^{* t *}(0.081) \\
0.150^{* \pm}(0.124) \\
0.208(0.222) \\
0.293(0.309) \\
0.616(0.779) \\
0.762^{* * t}(0.069)\end{array}$ \\
\hline $\begin{array}{l}\text { SlZE } \\
\text { 2. Betw. } 1 \text { and } 2 \text { million } \\
\text { 3. Betw. } 500000 \text { and } 1 \text { million } \\
\text { 4. Betw. } 250000 \text { and } 500000 \\
\text { 5. Less than } 250000\end{array}$ & $\begin{array}{l}2.933^{\star \pm}(1.612) \\
1.814(1.063) \\
4.879^{* \star}(3.175) \\
5.054^{\star}(4.586)\end{array}$ & $\begin{array}{l}2.898^{*}(1.630) \\
2.123(1.302) \\
4.722^{* *}(3.144) \\
5.267^{*}(4.772)\end{array}$ \\
\hline $\begin{array}{l}\text { RURALURB } \\
\text { 1.Rural }\end{array}$ & $0.510^{\star * * *}(0.140)$ & $0.461^{\star 25 *}(.132)$ \\
\hline
\end{tabular}

Note: ${ }^{*},{ }^{* *},{ }^{* * *}$ mean significantly different from zero at the $0.10,0.05,0.01$ significance level. 